\title{
Early Middle Pleistocene Ellobius (Rodentia, Cricetidae, Arvicolinae) from Armenia
}

\begin{abstract}
Alexey S. Tesakov
ABSTRACT. A large mole vole from the early Middle Pleistocene of Armenia shows morphological features and hyposodonty intermediate between basal Early Pleistocene E. tarchancutensis and the late Middle Pleistocene to Recent southern mole vole E. lutescens. The occlusal morphology of the first lower molar is similar to Early Pleistocene forms but hypsodonty values do not overlap either with Early Pleistocene mole voles (higher in the described form) or with extant E. lutescens (lower in the described form); these features characterise the Armenian form as a new chronospecies Ellobius (Bramus) pomeli sp.n., ancestral to the extant southern mole vole. Three phyletic lineages leading to two extant Asian species and to Pleistocene North African group of mole voles are suggested within Ellobius (Bramus).
\end{abstract}

KEY WORDS: Ellobius, Bramus, phylogeny, early Middle Pleistocene, Armenia.

Alexey S. Tesakov [tesak@ginras.ru], Geological Institute of the Russian Academy of Sciences, Pyzhevsky str., 7, Moscow 119017, Russia.

\section{Слепушонка Ellobius (Rodentia, Cricetidae, Arvicolinae) начала среднего плейстоцена Армении}

\begin{abstract}
А.С.Тесаков
РЕЗЮМЕ. Ископаемая крупная слепушонка из отложений начала среднего плейстоцена Армении по морфологии и гипсодонтии занимает промежуточное положение между раннеплейстоценовыми E. tarchancutensis и современной закавказской слепушонкой E. lutescens. По строению жевательной поверхности арямянская форма близка к раннеплейстоценовым слепушонкам, а значения гипсодонтии у этой формы занимают промежуточное положение и не перекрываются ни с формами раннего плейстоцена (выше у описываемой формы), ни с современной E. lutescens (ниже у армянской формы). Эти признаки характеризуют новый хроновид Ellobius (Bramus) pomeli sp.n., предковый по отношению к современной E. lutescens. Предложено рассматривать внутри Ellobius (Bramus) три филетические линии, ведущие к современным азиатским видам и ископаемым плейстоценовым слепушонкам Северной Африки.
\end{abstract}

КЛЮЧЕВЫЕ СЛОВА: Ellobius, Bramus, филогения, начало среднего плейстоцена, Армения.

\section{Introduction}

Mole voles (Ellobiusini, Arvicolinae, Cricetidae) are highly specialised burrowing cricetid rodents. The combination of specific cranial structure and molar teeth with plesiomorphic features (e.g. root formation and moderate hypsodonty) suggested for some systematists a position of mole voles outside the subfamily Arvicolinae (Miller, 1896). In their thorough revision of voles, Gromov \& Polyakov (1992) considered mole voles as vole-toothed cricetines convergent with arvicolines in dental morphology. In many other revisions Ellobiusini were included in the family/subfamily Arvicolidae (Hinton, 1926; Stehlin \& Schaub, 1951; Kretzoi, 1969). Recent data on molecular phylogeny of the Arvicolinae show a close sister-group relationships of Ellobiusini, Lagurini, and Microtini, thus supporting the hypothesis of mole voles being a part of the second
(Early Pliocene) radiation of Arvicolinae (Abramson et al., 2009a, b). Therefore, most specific features of mole voles developed due to a strong burrowing specialization (incisor digging, molar enamel thickening and partial reduction of molars) so that Early Pleistocene forms still show much more arvicoline-looking molars with some mimomyoid characters (e.g. Mimomys-ridge and relics of enamel islets). As with many rapidly evolving arvicoline phylums, molar evolution in mole voles shows a progressive hypsodonty increase from Early Pleistocene to Recent forms expressed in lengthening of dentine tracts of enamel-dentine boundary (Topachevsky \& Rekovets, 1982; Zazhigin, 1988; Tesakov, 2008; Fig. 2). Two main branches of mole voles are recognised (Fig. 3). The nominotypical subgenus Ellobius (Ellobius) Fischer, 1814 combines smaller mole voles with the fossil record ranging from Early Pleistocene to recent (Topachevsky \& Rekovets, 1982; Tjutkova, 1989; 
Tesakov, 2008). The group of larger forms is included in the subgenus Bramus Pomel, 1892. This name has a priority over Afganomys Topachevsky, 1965 commonly used for this group in the literature (Tesakov, 2008). This subgenus is represented by two extant species of western and central Asia, the southern (E. lutescens Thomas, 1897) and Afghan (E. fuscocapillus Blyth, 1842) mole voles. These species were often considered conspecific (Ognev, 1950), but substantial chromosomal and marked morphological differences support their status as distinct species (Vorontsov et al., 1980; Carleton \& Musser, 2005).

The fossil record of E. (Bramus) is patchy. The most impressive is the Early to Middle Pleistocene record of the group in North Africa where after a migration from Asia a short but conspicuous endemic evolution occurred with several successive species known (Pomel, 1892; Jaeger, 1988; Geraads, 2002; Stoetzel, 2013).

In the range and adjacent areas of the recent Afghan mole vole, there are records of a basal form from the early Early Pleistocene (Gelasian) of Kazakhstan, E. primigenius Savinov, and late Early Pleistocene species from Tadjikstan, E. lakhutensis Zazhigin (Lytchev \& Savinov, 1974; Zazhigin, 1988). In the south of Eastern Europe there are several records of Early Pleistocene (Calabrian) E. tarchancutensis Topachevsky (Topachevsky, 1963; Tesakov, 2008). The morphology of this vole tentatively points to its ancestral position relative to the recent southern vole $E$. lutescens of Transcaucasus, northern Iran, and eastern Asia Minor (Tesakov, 2008). Fossil records of late Middle to Late Pleistocene E. lutescens are known from archaeological sites of the Near East (Bate, 1937; Tchernov, 1968; Maul et al., 2015); these were originally considered as a separate species E. pedorychus Bate, 1937 or a subspecies of the southern mole vole. The new record of a larger mole vole from Armenia sheds light on a ca. 1 Myr gap in the known history of Ellobius (Bramus) in the western Asia.

The early Middle Pleistocene deposits of the Shirak Depression exposed in numerous outcrops near the city of Gyumri in western Armenia are assigned to the fluvio-lacustrine Arapi Formation (Sayadyan, 2009; Trifonov et al., 2016). These deposits have yielded a rich biotic record including large and small mammals and freshwater molluscs (Akramowski, 1956; Avakyan, 1959; Melik-Adamyan, 1994, 2004; Agadjanyan \& Melik-Adamyan, 1985). On the basis of the large mammals, notably Mammuthus trogontherii (Pohlig), the deposits were assigned to the Leninakan or, later, Gyumri faunal complex (assemblage) correlated with mid Middle Pleistocene Singilian assemblage of Eastern Europe (Sayadyan, 1970, 2009; Alekseeva, 1977). Melik-Adamyan (1994, 2004) argued for an older age of the Arapi deposits. Based on the composition of the small mammal faunas and radiometric dates he correlated the Gyumri assemblage to the early Middle Pleistocene, Cromerian of Western Europe, and Tiraspolian com- plex (assemblage) of Eastern Europe. The records of Mammuthus trogontherii (Alekseeva, 1977), small mammals with basal Terricola, advanced Prolagurus pannonicus Kormos and Mimomys intermedius Newton (Agadjanian \& Melik-Adamyan, 1985), radiometric dates of 0.6-0.7 Ma for "Leninakan tuffs" covering or interfingering with Arapi deposits, and normal polarity (Brunhes Chron) of these deposits (Trifonov et al., 2016) point to the early Middle Pleistocene age of the Gyumri faunal assemblage.

In 2013, a new early Middle Pleistocene mammalian fauna was discovered by the expedition of the Geological Institute of the Russian Academy of Sciences headed by V.G. Trifonov. A four meters thick fluviatile deposits exposed in a sandpit near Krasar settlement in the upper Akhurian Basin yielded a mammalian assemblage including Ochotona sp., Terricola cf. majori Thomas, Microtus sp., Ellobius (Bramus) pomeli sp.n., Elephantidae gen. indet., Praemegaceros cf. verticornis (Dawkins), cf. Bison sp. (Trifonov et al., 2016, and additional data). Normal polarity of the deposits and their faunal composition point to the correlation to the Arapi Formation of western Armenia. Additional material on mole vole has been collected in 2016 from the Arapi deposits of Haykadzor locality located in the Shirak Basin. This site yielded remains of Terricola ex gr. majori, Mimomys intermedius, Prolagurus pannonicus transylvanicus Terzea, and Ellobius pomeli sp.n.

The find of isolated molars of mole vole from early Middle Pleistocene deposits of Armenia is an important record for reconstructing the history of this group of arvicolines. In 2013, remains of a large mole vole (a damaged M2) was found in another early Middle Pleistocene locality in the Shirak Basin, Armenia, at Lusaghbyur (Agadjanian \& Melik-Adamyan, 2016).

\section{Material and methods}

Remains of small mammals were collected in the field using standard dry-sieving techniques with the mesh size of $1 \mathrm{~mm}$. Occlusal elements of vole mole molars are named according to van der Meulen (1973). Measurements are after Tesakov (2004). Terms for dentine tracts (sinuous enamel-dentine boundary folds) in dentitions of rhizodont voles follow G. Rabeder (1981): HH-index, the square root of the sum of squared heights of dentine tracts of hypoconid and hypoconulid in lower molars; ASD - anterosinuid, HSD — hyposinuid, HSLD - hyposinulid, MIM - mimosinuid. Lower case $\mathrm{m}$ stands for lower molars; upper case M, for upper molars. T stands for dental triangle; A, anteroconid length; $\mathrm{H}$, labial height; $\mathrm{R}$, root height in labial view; Lbas, basal length. All measurements are in mm. Institutional abbreviation: GIN, Geological Institute of the Russian Academy of Sciences, Moscow; ZISP, Zoological Institute of the Russian Academy of Sciences, Saint Petersburg. 


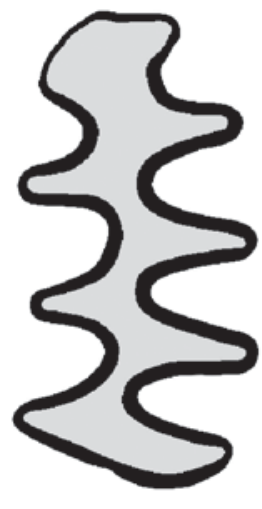

1

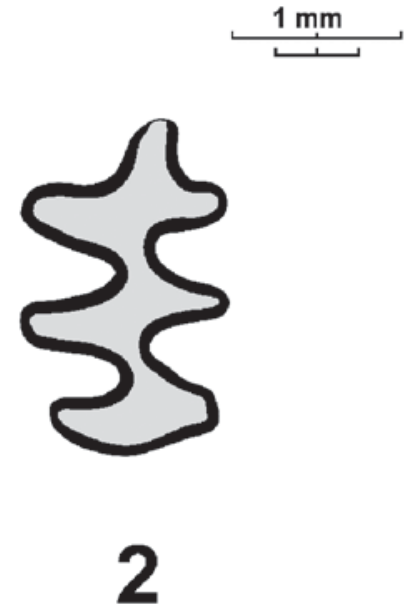

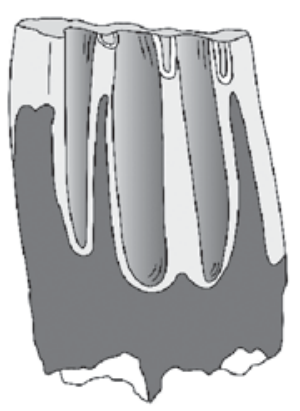

1a

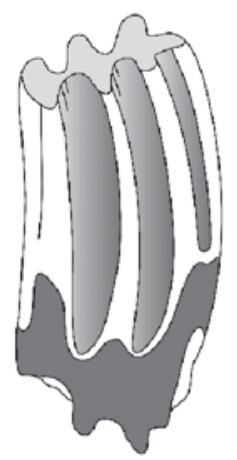

$2 a$

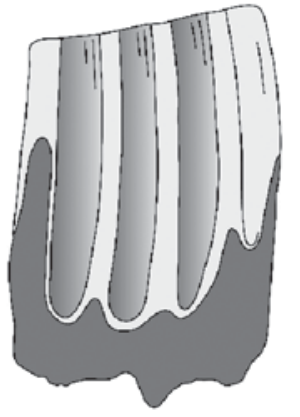

$1 b$

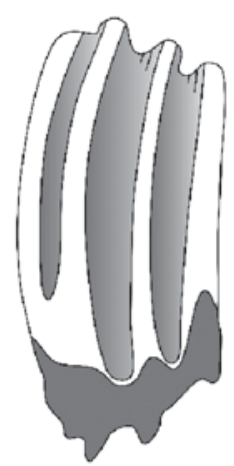

$2 b$
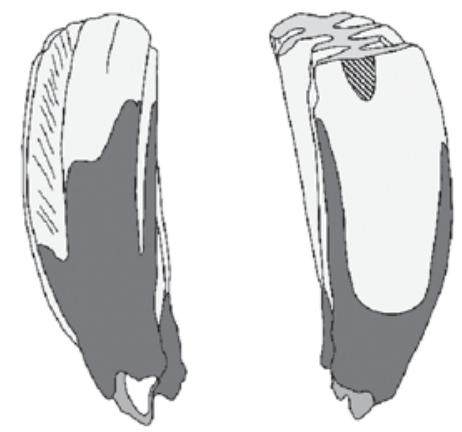

$1 \mathrm{c}$
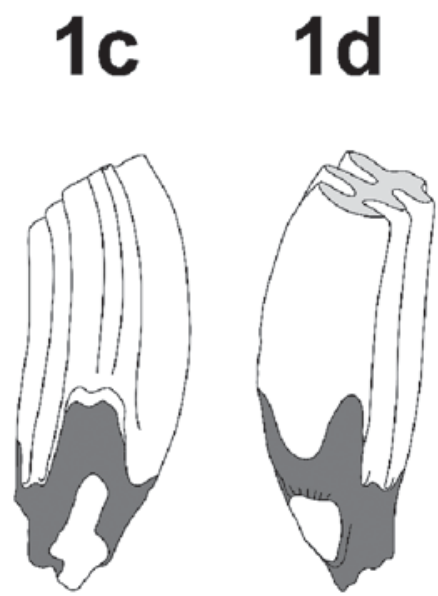

2c

Fig. 1. Ellobius (Bramus) pomeli sp.n. 1 - first lower molar, m1, left side, occlusal view, Krasar; 2 - second lower molar, $\mathrm{m} 2$, right side, Haykadzor. Lateral views: $\mathrm{a}$ - labial; $\mathrm{b}$ - lingual; $\mathrm{c}$ — anterior; $\mathrm{d}$ - posterior. Scale bars for occlusal (upper) and lateral (lower) views equal $1 \mathrm{~mm}$.

\section{Systematic paleontology}

Order Rodentia Bowdich, 1821

Family Cricetidae Fischer, 1817

Subfamily Arvicolinae Gray, 1821

Tribe Ellobiusini Gill, 1872

Genus Ellobius Fischer, 1814

Subgenus Bramus Pomel, 1892

\section{Ellobius (Bramus) pomeli sp.n.}

Fig. 1.

Ellobius ex gr. lutescens: Trifonov et al., 2016: p.12, fig. 9: 1. Ellobius (Bramus) ex gr. lutescens: Tesakov, 2016: p.420.

Etymology: In honour of Auguste Pomel, eminent French paleontologist who made an important contribution to the study of Pleistocene larger Ellobiusini.

Holotype: GIN-1141/1, isolated right first lower molar, $\mathrm{L}=2.8, \mathrm{~W}=1.35, \mathrm{~A}=1.15, \mathrm{H}=2.9, \mathrm{R}=1.25$, $\mathrm{ASD}=2.3, \mathrm{MIM}=2.4, \mathrm{HSD}=2.32, \mathrm{HSLD}=2.25$, Lbas $=3.1, \mathrm{HH}$-index $=3.23$.
Type locality and geological age. $\operatorname{Krasar}\left(\mathrm{N} 41^{\circ} 00\right.$. 753', E4349.872'; H = 1981 m a.s.1.), Arapi Formation, Upper Akhurian Basin, north-western Armenia; early Middle Pleistocene, late Biharian, Tiraspolian faunal complex, East European regional biochronological unit MQR7.

Additional material: GIN-1142/1, isolated left second lower molar, $\mathrm{L}=2.0, \mathrm{~W}=1.16, \mathrm{H}=1.55, \mathrm{R}=1.0$, $\mathrm{ASD}=1.2, \mathrm{HSD}=1.05, \mathrm{HSLD}=1.1, \mathrm{Lbas}=2.3, \mathrm{HH}-$ index $=1.52$. Haykadzor $\left(\mathrm{N} 41^{\circ} 32.26^{\prime}, \mathrm{E} 43^{\circ} 39.31^{\prime} ; \mathrm{H}=\right.$ 1488 m a.s.1.), Arapi Formation, Shirak Basin, northwestern Armenia; early Middle Pleistocene, late Biharian, Tiraspolian faunal complex, East European regional biochronological unit MQR7.

Diagnosis. Medium size Bramus with hypsodonty HH-index near 3, short anteroconid, and occlusal confluence between of T4 and T5 broader than that of T3 and T4.

Differential diagnosis. The new species differs from Early Pleistocene forms E.(B.) primigenius Lytchev et Savinov, 1974 of Kazakhstan (Gelasian), E.(B.) tarchancutensis Topachevsky, 1963 (early to mid Calabrian) 

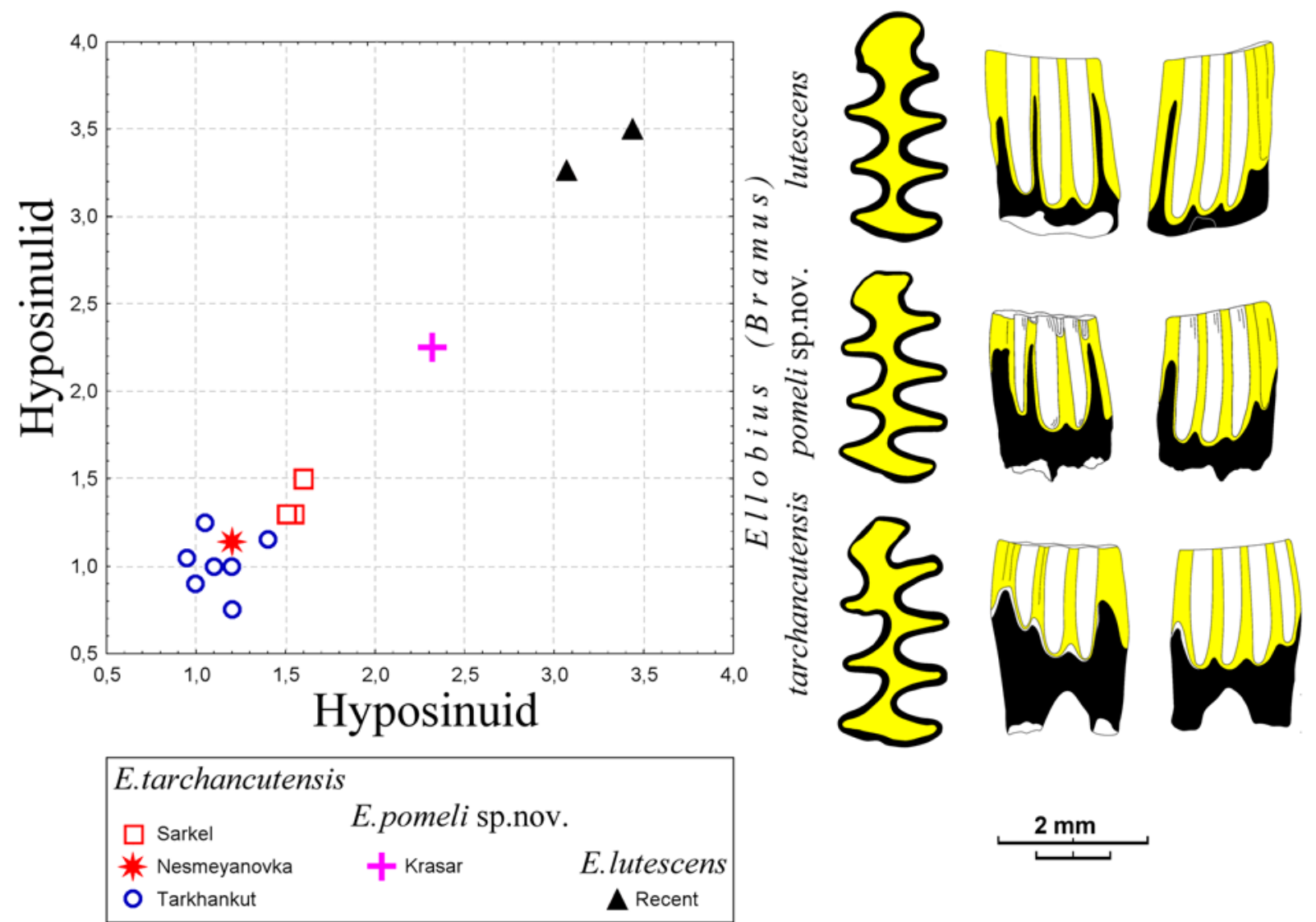

Fig. 2. Hypsodonty diagram of some fossil and recent mole voles Ellobius (Bramus). Hyposinuid, labial dentine tract of posterior loop of $\mathrm{ml}, \mathrm{mm}$; hyposinulid, lingual dentine tract of posterior loop of $\mathrm{ml}, \mathrm{mm}$. Note a difference in dentine tract height, as a marker of hypsodonty, in Early Pleistocene E. tarchancutensis (Sarkel locality, GIN-EMM-139/21) through early Middle Pleistocene E. pomeli sp.n. to Recent E. lutescens (ZISP-35390, Vedi, Armenia).

of southern Eastern Europe, and E.(B.) africanus Jaeger, 1988 from North Africa (late Calabrian?) in higher hypsodonty $(\mathrm{HH}$-index $=3.2$ compared to $\leq 1.5)$. Ellobius (Bramus) pomeli sp.n. differs from late Middle to recent Ellobius lutescens Thomas, 1897 including E. lutescens pedorychus Bate, 1937 in lower hypsodonty (HH-index $=3.2 \mathrm{vs}>4$ in compared forms) and in stronger alternating basic triangles (T1-T3) and more opposing anteroconid triangles (T4-T5). The described species differs from late Early Pleistocene Ellobius lakhutensis Zazhigin, 1988 from Tadjikstan and from recent Afghan mole vole E. fuscocapillus Blyth, 1842 in smaller size, lower hypsodonty (HH-index $=3.2 \mathrm{vs} \geq$ 4 in the compared forms), and from the latter form in more alternating basic triangles. From North African Middle-Late Pleistocene species, E. pomeli sp. nov differs in smaller size and higher hypsodonty.

Description. The first lower molar (Fig. 1: 1) shows moderately high crown and two roots. The enamel is mostly uniformly thick with a notable thinning along the anterolabial side of the anteroconid cap. The closing enamel of the posterior lobe bears an attritional facet of $\mathrm{m} 2$. The molar has a well developed posterior lobe, three basic triangles (T1-T3), anteroconid trian- gles T4-T5, and a slightly transversely elongated suboval anteroconid cap (Fig. 1). Occlusal dentine fields broadly communicate, with broadest connections between T1-T2 and anteroconid elements. The reentrant angles are U-shaped. Dentine tracts are of medium height. Hyposinuid is somewhat higher than hyposinulid. Mimosinuid is well developed, matching the height of hyposinuid. The tip of anterosinuid is slightly bilobate. The anterosinuid bears a notable indentation on the anterior side of the anteroconid. Apart from hyposinulid, the tracts of the lingual side are low, except for a slightly higher tract of LSA4 (1.1 mm).

Lower $\mathrm{m} 2$ from Haykadzor (Fig. 1:2) has a relatively high crown and two distinct roots. The enamel is thick, with some thinning in the corners of reentrant angles, and at the tips of salient elements The molar has two pairs of occlusal triangles (T1-T2 and T3-T4) and posterior loop. All occlusal elements broadly communicate, with the triangles showing broader pair-wise confluence. At the same time the triangles display notable alternation with labial elements shifted in an anterior direction compared to their lingual counterparts. The anterior portion of the molar has a distinct, pointed anteroconid delimited by two deep reentrants, BRA3 


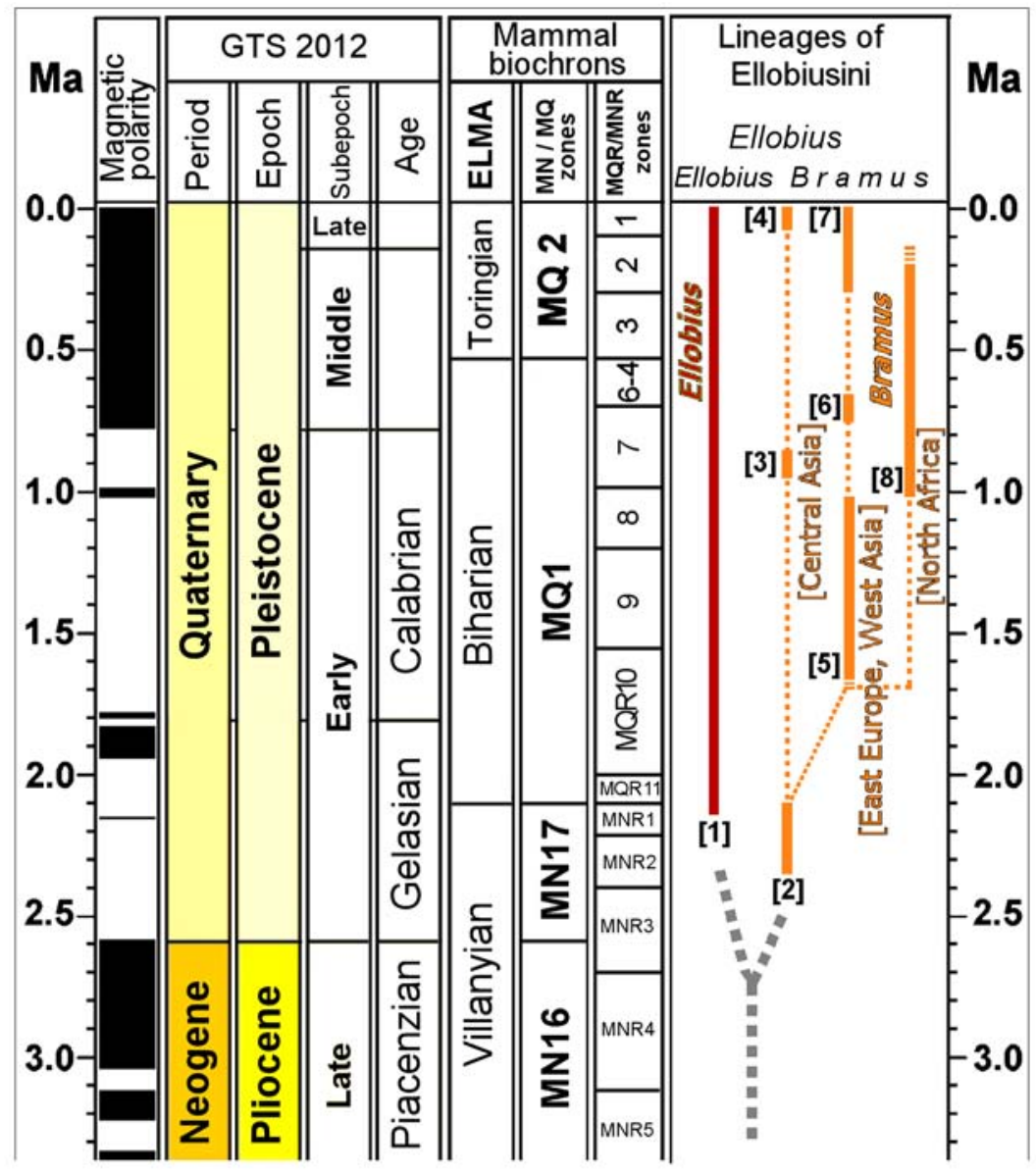

Fig. 3. Chronology of reconstructed phyletic lineages of Ellobius (Bramus). Documented intervals of the lineages: nominative subgenus Ellobius (Ellobius), smaller mole voles: [1]; subgenus of larger mole voles, Ellobius (Bramus): [2] E. primigenius (early Early Pleistocene, southern Kazakhstan, Turkmenistan), archetypical ancestor of larger mole voles; [3] E. lakhutensis (latest Early Pleistocene, Tadjikistan); [4] E. fuscocapillus (Recent, Central Asia); [5] E. tarchancutensis (late Early Pleistocene, East Europe, West Asia, ?North Africa); [6] E. pomeli sp.n. (early Middle Pleistocene, Armenia); [7] E. lutescens (late Middle to Late Pleistocene, Recent, West Asia); [8] E. spp. (late Early to Middle Pleistocene, North Africa). Geochronologic and paleomagnetic scales are according to Geological Time Scale 2012 (Hilgen et al., 2012; Pillans \& Gibbard, 2012). Mammal biochrons are according to Pevzner et al. (2001) modified; Tesakov et al. (2007), modified; Hilgen et al. (2012); Tesakov \& Titov (2013).

and LRA3. Dentine tracts are clearly expressed. The tip of anterosinuid is bilobate.

\section{Discussion}

The mole vole Ellobius (Bramus) pomeli sp.n. in hypsodonty of $\mathrm{m} 1$ has an intermediate position (Fig. 2) between the Early Pleistocene (Calabrian) Ellobius tarchancutensis Topachevsky of Eastern Europe (Crimea, lower Don River area) (Tesakov, 2008) and the extant southern mole vole Ellobius lutescens (Transcaucasus, eastern Turkey, north-western Iran) and its fossil forms including late Middle Pleistocene E. lutescens from Azykh (Azokh) Cave in eastern Transcaucasus (Markova, 1982; Parfitt, 2016), and late Middle Pleistocene to Late Pleistocene Ellobius lutescens pe- dorychus Bate from Israel (Bate, 1937; Tchernov, 1968). These former forms include the type E. l. pedorychus from Late Pleistocene Levallois-Mousterian beds of Tabun Cave and an older form from late Middle Pleistocene Acheulian beds of the Oumm-Qatafa archaeological site (Tchernov, 1968). On the other hand, in occlusal structure with well alternating triangles and well separated anteroconid, early Middle Pleistocene Ellobius pomeli sp.n. is most similar to advanced E. tarchancutensis from Early Pleistocene fauna of Sarkel (Tesakov, 2008). It differs from late Middle Pleistocene to Recent forms of E. lutescens (e.g. Markova, 1982; Kryštufek \& Vohralík, 2005; Coşkun, 2016) which show a broad confluence of dental triangles with a trend to pair-wise opposing of T1-T2 and T3-T4, and separation of T5 getting confluent to the anteroconid cap. 
In fact, a placement of ancient mole voles from Europe and Asia to the lineages of either of the two extant Eurasian species is hampered by plesiomorphic traits in the fossil forms. The dental differences apparent between recent $E$. lutescens and $E$. fuscocapillus are not easily traceable back in time. For example, E. lutescens is slightly smaller than E. fuscocapillus (Moradi Gharkheloo \& Kivanç, 2003), E. lutescens has a less anteroposteriorly extended $\mathrm{m} 1$, and a slightly less pairwise opposed T1-T2 and T3-T4. More differences are apparent in cranial and dental characters (Ognev, 1950; Kryštufek \& Vohralík, 2005). In this situation, the geographic occurrence coupled with morphological evidence is the only way to set up a phyletic hypothesis. Thus the Transcaucasian location of E. pomeli sp. nov. combined with its intermediate hypsodonty suggests that the Armenian form is a chronological stage of the lineage of recent $E$. lutescens. The reconstructed lineage of E. pimigenius $-E$. tarchankutensis $-E$. pomeli sp.n.-E. lutescens then shows a relatively uniform increase of hypsodonty through time. On the other hand, most of occlusal changes from alternating to opposing triangles conditions should have occurred in a short period between early and late Middle Pleistocene. A form only slightly older than the Armenian mole vole, the late Early Pleistocene E. lakhutensis Zazhigin from Tadjikistan shows characters not compatible with the lineage considered above. Firstly, regardless of its older age, the Tadjik form is somewhat larger and more hypsodont than E. pomeli sp.n. Secondly, E. lakhutensis has a more robust anteroconid in $\mathrm{m} 1$. It makes sense to regard this form as a part of another lineage leading to extant E. fuscocapillus.

\section{Lineages of Ellobius (Bramus)}

The basal Early Pleistocene forms of Ellobius (Bra$m u s$ ) include the oldest and archetypically basal $E$. primigenius from Gelasian Kiikbai fauna of southern Kazakhstan (Lytchev \& Savinov, 1974), the Tarkhankut vole, E. tarchancutensis, known from several Calabrian localities in southern Eastern Europe, and morphologically very similar to East European forms $E$. africanus Jaeger from latest Early Pleistocene Tighenif (Ternifine) locality in Algeria (North Africa).

Three distinct post-Early Pleistocene lineages are clearly defined in the group. Two lineages are definable for the recent species of Ellobius (Bramus). The lineage of the Afghan mole vole includes latest Early Pleistocene E. lakhutensis from Lakhuti 2 site in Tadjikistan (Zazhigin, 1988) and the recent E. fuscocapillus. The lineage of the southern mole vole includes $E$. pomeli sp. nov. from early Middle Pleistocene of Transcaucasus, E. l. pedorychus from late Middle to Late Pleistocene of the Near East, and the recent E. lutescens. The third one is Middle to Late Pleistocene extinct lineage from North Africa including E. atlanticus Jaeger, E. barbarus Pomel, and E. zimae Jaeger (Jaeger, 1988; Geraads, 1994, 2002). It was suggested that the North African group can in turn be split into two lineages (Jaeger, 1988). The origin of the African lineage by a migration of an Asian form is suggested (Jaeger, 1988). The earliest known East European and African forms (E. tarchancutensis and E. africanus respectively) share an almost identical plesiomorphic morphology and stage of evolution indicating a possible conspecificity of these forms. Therefore, the dispersal event of mole voles to Africa can be biochronologically dated to at least the middle part of the Early Pleistocene (Tesakov \& Geraads, 2009). The proposed lineages are illustrated in Fig. 3.

ACKNOWLEDGEMENTS. I sincerely thank Alexandra Simakova and Pavel Frolov for discovering in the field the fossils described in this paper. Vladimir Trifonov is thanked for guiding the studies of Cenozoic deposits in Armenia. Ara Avagyan and Lilit Sahakyan greatly helped during field work in Armenia. Vladimir Zazhigin is acknowledged for comparative material and stimulating discussion. I thank the reviewers, Simon Parfitt, Maxim Sinitsa, and Piroska Pazonyi, whose helpful suggestions helped to improve the text. Vladimir Lebedev (Zoological Museum of Moscow University), Olga Makarova (Zoological Institute of the Russian Academy of Sciences, Saint-Petersburg), and Yuri Semenov (National Museum of Natural History, National Academy of Sciences of Ukraine, Kiev) kindly provided access to zoological and paleontological collections in their care. This study was supported by the Russian Foundation for Basic Research, project numbers 1505-00358 and 15-55-05009.

\section{References}

Abramson N.I., Lebedev V.S., Tesakov A.S. \& Bannikova A.A. 2009a. Supraspecies relationships in the subfamily Arvicolinae (Rodentia, Cricetidae): an unexpected result of nuclear gene analysis // Molecular Biology. Vol.43. No.5. P.834-846.

Abramson N.I., Lebedev V.S., Bannikova A.A. \& Tesakov A.S. 2009b. Radiation events in the subfamily Arvicolinae (Rodentia): Evidence from nuclear genes // Doklady Biological Sciences. Vol.428. No.1. P.458-461.

Agadjanyan A.K. \& Melik-Adamyan G.U. 1985. [Early Pleistocene small mammals in the Shirak Basin of Armenia] // Bulletin of Commission for Study of the Quaternary. No.54. P.91-100 [in Russian].

Agadjanyan A.K. \& Melik-Adamyan G.U. 2016. [First record of fossil mole vole from Lower Neopleistocene of the Shirak Depression in Armenia] // Theriofauna of Russia and adjacent territories. International Conference. X Congress of the Russian Theriological Society RAS. Moscow 1-5, 2016. Moscow: KMK Scientific Press. P.13 [in Russian].

Akramowski N.N. 1956. [Pleistocene fresh-water mollusks from sand quarry near Leninakan] // Izvestiya (Proceedings) of the Academy of Sciences of the Armenian SSR, Biological and Agricultural Sciences. Vol.9. No.1. P.8190 [in Russian]. 
Alekseeva L.I. 1977. [Early Anthropogene Teriofauna of Eastern Europe]. Moscow: Izdatel'stvo Nauka. 214 p. [in Russian].

Avakyan L.A. 1959. [Quaternary mammalian fauna in Armenia]. Yerevan: Academy of Sciences of the Armenian SSR. 71 p. [in Russian].

Bate D.M.A. 1937. New Pleistocene Mammals from Palestine // Annals and Magazine of Natural History, London, Ser. 10. Vol.20. P.397-400.

Carleton M.D. \& Musser G.G. 2005. Subfamily Arvicolinae // Wilson D.E. \& Reeder D.M. (eds.). Mammal Species of the World. Third edition. Vol.2. Baltimore, Maryland: Johns Hopkins University Press. P.956-1039.

Co kun Y. 2016. Review of unique odd chromosome-numbered underground rodent species of the Palearctic region: Ellobius lutescens Thomas 1897 (Rodentia: Cricetidae)// Turkish Journal of Zoology. Vol.40. doi:10.3906/ zoo-1509-53.

Geraads D. 1994. Rongeurs et lagomorphes du Pléistocène moyen de la "Grotte des Rhinocéros", carrière Oulad Hamida 1, à Casablanca, Maroc // Neues Jahrbuch für Geologie und Paläontologie, Abhandlungen. Vol.191. No.2. P.147-172.

Geraads D. 2002. Plio-Pleistocene mammalian biostratigraphy of Atlantic Morocco // Quaternaire. Vol.13. No.1. P.43-53.

Gromov I.M. \& Polyakov I.Y. 1992. Fauna of the USSR: Mammals. Vol. III, No.8. Voles (Microtinae). Smithsonian Institution Libraries \& National Science Foundation, Washington, D.C. New Delhi: Oxonian Press. $725 \mathrm{p}$.

Hilgen F.J., Lourens L.J. \& van Dam J.A., 2012. The Neogene Period // Gradstein F.M., Ogg J.G., Schmitz M.D. \& Ogg G. (eds.). The Geologic Time Scale 2012. Amsterdam: Elsevier. P.923-978.

Hinton M.A.C. 1926. Monograph of the Voles and Lemmings (Microtinae) Living and Extinct. London: British Museum (Natural History). Vol.1. 488 p.

Jaeger J.-J. 1988. Origine et évolution du genre Ellobius (Mammalia, Rodentia) en Afrique Nord-Occidentale // Folia Quaternaria. Vol.57. P.3-50.

Kretzoi M. 1969. Skizze einer Arvicoliden Phylogenie Stand 1969 // Vertebrata Hungarica. Vol.11. No.1-2. P.155-193.

Kryštufek B. \& Vohralík V. 2005. Mammals of Turkey and Cyprus. Rodentia I: Sciuridae, Dipodidae, Gliridae, Arvicolinae. Koper: Univerza na Primorskem. 286 p.

Lytchev G.F. \& Savinov P.F. 1974. [Late Pliocene lagomorphs and rodents from Kiikbai] // Materialy po Istorii i Faune Kazakhstana. Vol.6. P.39-57 [in Russian].

Markova A.K. 1982. [Small mammal fauna from Paleolithic cave site Azykh] // Paleontologicheskii Sbornik (Lvov). Vol.19. P.14-28 [in Russian].

Maul L., Smith K.T., Shenbrot G., Bruch A., Wegmüller F. \& Le Tensorer J.-M. 2015. Microvertebrates from unit G/layer 17 of the archaeological site of Hummal (El Kowm, Central Syria): Preliminary results // L'anthropologie. Vol.119. P.676-686.

Melik-Adamyan G.U. 1994. [On the upper biostratigraphic boundary of ignimbrites of the Kasakh-Pambak type in
Armenia] // Izvestiya (Proceedings) of the National Academy of Sciences of the Republic of Armenia, Earth's Sciences. Vol.47. No.3. P.9-12 [in Russian].

Melik-Adamyan G.U. 2004. [Stratigraphic significance of the Neopleistocene theriofauna of the Shirak depression] // Izvestiya (Proceedings) of the National Academy of Sciences of the Republic of Armenia, Earth Sciences. Vol.57. No.3. P.27-31 [in Russian].

Meulen A. van der. 1973. Middle Pleistocene smaller mammals from the Monte Peglia (Orivieto, Italy) with special reference to the phylogeny of Microtus (Arvicolidae, Rodentia)// Quaternaria. Vol.17. P.1-144.

Miller G.S. 1896. Genera and subgenera of voles and lemmings // North American Fauna. Vol.12. P.1-85.

Moradi Gharkheloo M. \& Kivanç E. 2003. A study on the morphology, karyology and distribution of Ellobius Fisher, 1814 (Mammalia: Rodentia) in Iran // Turkish Journal of Zoology. Vol.27. P.281-292.

Ognev S.I. 1950. [Mammals of the USSR and Adjacent Countries. Vol.7. Rodents]. Moscow-Leningrad: AN SSSR Publ. 626 p. [in Russian].

Parfitt S. 2016. Rodents, lagomorphs and insectivores from Azokh Cave // Férnandez-Jalvo Y. (ed.). Azokh Cave and the Transcaucasian Corridor // Vertebrate Paleobiology and Paleoanthropology. Dordrecht: Springer Science + Business Media. P.163-176.

Pevzner M. A.,Vangengeim E.A. \& Tesakov A.S. 2001. Quaternary zonal subdivision of Eastern Europe based on vole evolution // Bolletino della Società Paleontologia Italiana. Vol.40. No.2. P.269-274.

Pillans B. \& Gibbard P. 2012. The Quaternary period // Gradstein F.M., Ogg J.G., Schmitz M.D. \& Ogg G. (eds.). The Geologic Time Scale 2012. Amsterdam: Elsevier. P.979-1010.

Pomel A. 1892. Sur le Bramus, nuveau type de rongeurs fossile des phosphorites quaternaires de la Berbérie // Comptes Rendus de l'Academie des Sciences. No.114. P.1159-1169.

Rabeder G. 1981. Die Arvicoliden (Rodentia, Mammalia) aus dem Pliozän und dem älterem Pleistozän von Niederösterreich. Beiträge zur Paläontologie von Österreich. Vol.8. P.1-343.

Sayadyan Yu.V. 1970. [Stratigraphic position and paleogeographic significance of mammalian fauna of the Leninakan faunal assemblage] // Bulletin of Commission for Study of the Quaternary. No.39. P.63-67 [in Russian].

Sayadyan Yu.V. 2009. [The Newest Geological History of Armenia]. Yerevan: Ghitutyun. 357 p. [in Russian].

Stehlin H.G. \& Schaub S. 1951. Die Trigonodontie der simplicidentaten Nager // Abhandlungen der Schweizerischen Palaeontologischen Gesellschaft. Vol.67. P.1385.

Stoetzel E. 2013. Late Cenozoic micromammal biochronology of northwestern Africa // Palaeogeography, Palaeoclimatology, Palaeoecology. Vol.392. P.359-381.

Tchernov E. 1968. Succession of Rodent Faunas During the Upper Pleistocene of Israel. Hamburg, Berlin: Paul Parey. $153 \mathrm{p}$.

Tesakov A.S. 2004. [Biostratigraphy of Middle Pliocene Eopleistocene of Eastern Europe (based on small mam- 
mals)]. Moscow: Izdatel'stvo Nauka. 247 p. [in Russian].

Tesakov A.S. 2008. Early Pleistocene mammalian fauna of Sarkel (Lower Don River area, Russia): mole voles (Ellobiusini, Rodentia)// Russian Journal of Theriology. Vol.7. No.2. P.81-88.

Tesakov A.S. 2016. [Ancient Transcaucasian mole vole from early Middle Pleistocene of Armenia] // Theriofauna of Russia and adjacent territories. International Conference. X Congress of the Russian Theriological Society RAS. Moscow 1-5, 2016. Moscow: KMK Scientific Press. P.420 [in Russian].

Tesakov A.S. \& Geraads D. 2009. Mole voles (Ellobiusini, Arvicolinae) as markers of Early Pleistocene EurasianAfrican biotic connections // The Quaternary of southern Spain: a bridge between Africa and the Alpine domain. Orce. 2009 annual meeting SEQS. Abstract volume. Tarragona: Universitat Rovira i Virgili. P.52-53.

Tesakov A.S. \& Titov V.V. 2013. [Biostratigraphic grounds of subdivision of terrestrial Lower Pleistocene (Gelasian + Calabrian) in Russia] // VIII All-Russian Conference on Quaternary Research. Fundamental problems of Quaternary, results and main trends of future studies. Rostov-on-Don, 10-15 June 2013. Collection of papers. Rostov-on-Don: Southern Scientific Centre RAS. P.628 630 [in Russian].

Tesakov A.S., Vangengeim E.A. \& Pevzner M.A. 2007. Arvicolid zonation of continental Pliocene deposits of East Europe // Courier Forschungsinstitut Senckenberg. Vol.259. P.229-236.
Topachevsky V.A. 1963. [New vole species (Rodentia, Microtinae) from the Upper Pliocene and Lower Anthropogene deposits of the southern Ukraine and Crimea] // Dopovidi Akademii Nauk Ukrainskoi SSR. No.1. P.100103 [in Ukrainian].

Topachevsky V.A. 1965. [Insectivores and Rodents of the Late Pliocene Fauna of Nogaisk]. Kiev: Naukova Dumka. 163 p. [in Russian].

Topachevsky V.A. \& Rekovets L.I. 1982. [New materials for taxonomy and evolution of Ellobius s.str. (Rodentia, Cricetidae)] // Vestnik Zoologii. No.5. P.47-54 [in Russian, with English summary].

Trifonov V.G., Lyubin V.P., Belyaeva E.N., Lebedev V.A., Trikhunkov Ya.I., Tesakov A.S., Simakova A.N., Veselovsky R.V., Latyshev A.V., Presnyakov S.L., Ivanova T.P., Ozhereliev D.V., Bachmanov D.M. \& Lyapunov S.M. 2016. Stratigraphic and tectonic settings of Early Paleolithic of North-West Armenia // Quaternary International. doi: 10.1016/j.quaint.2015.08.019.

Tjutkova L.A. 1989. [A new species of mole-vole (Rodentia) from the Late Pliocene of south-western Kazakhstan] // Paleontological Journal. No.2. P.123-127 [in Russian].

Vorontsov N.N., Lyapunova E.A., Borisov Yu.M. \& Dovgal V.E. 1980. Variability of sex chromosomes in mammals // Genetica. Vol.52/53. P.361-372.

Zazhigin V.S. 1988. [Paleontological descriptions: Insectivora, Lagomorpha, Rodentia] // Vangengeim E.A. \& Nikiforova K.V. (eds.). [Biostratigraphy of Late PlioceneEarly Pleistocene of Tadzhikistan (Mammalian Fauna)]. Moscow: Izdatel'stvo Nauka. P.18-24 [in Russian]. 